\title{
Microbial activity and community level physiological profiles (CLPP) of soil under the cultivation of spring rape with the Roundup $360 \mathrm{SL}$ herbicide
}

\author{
Stefania Jezierska-Tys ${ }^{1}$. Jolanta Joniec ${ }^{1}$ (D) Agnieszka Mocek-Płóciniak ${ }^{2} \cdot$ Anna Gałązka $^{3} \cdot$ Joanna Bednarz $^{1}$. \\ Karolina Furtak ${ }^{3}$
}

Received: 22 May 2020 / Accepted: 23 October 2021 / Published online: 12 November 2021

(C) The Author(s) 2021

\begin{abstract}
Purpose The use of glyphosate in agriculture raises a lot of controversy because research concerning its impact on the soil provides contradictory information. However, despite these negative opinions, glyphosate is still used in agricultural practice. Therefore, for a more complete assessment, the authors carried out research using traditional microbiological methods and a modern method of metabolic profile analysis in glyphosate-treated soil.

Methods The study was carried out on the soil witch was sown with six cultivars of rapeseed. Seven days before harvest, the plants were sprayed with the herbicide. The analyses consisted in determining the number of selected groups of microorganisms, biochemical and enzymatic activity, and differentiation of the catabolic potential of soil microbial communities. Results The results showed significant changes in the analyzed parameters. Respiratory activity and ammonification processes were stimulated in the treatments with rapeseed cultivation treated with the herbicide. Changes in the enzymatic activity were generally positive. The EcoPlate assessment of microbial community catabolism showed that the highest activity was recorded in the soil sown with the cultivars Belinda, Tamarin, and Sw svinto. Concurrently, these soils were characterized by the highest correlations between rapeseed cultivar and metabolic activity. Conclusion Cultivation of specific plant varieties that reduce the negative effect of herbicides used in agriculture may be one of the methods to prevent soil degradation. In our research, Belinda turned out to be a cultivar, under the cultivation of which an increase in the activity of microorganisms was recorded most frequently compared to soil not sown with rapeseed.
\end{abstract}

\section{Highlights}

- These studies were undertaken due to the importance of glyphosate in soil environment degradation.

- The results showed significant changes in the activity and diversity of microorganisms

- The nature and intensity of these changes depended on the time point and oilseed rape cultivar.

- The most favorable soil conditions for microorganisms were under the cultivar Belinda

Keywords Rapeseed $\cdot$ Biochemical and enzymatic activity $\cdot$ Catabolic diversity $\cdot$ Herbicide $\cdot$ Soil microorganisms

Jolanta Joniec

jolanta.joniec@up.lublin.pl

1 Department of Environmental Microbiology, Faculty of Agrobioengineering, University of Life Sciences in Lublin, Lublin, Poland

2 Department of General and Environmental Microbiology, Faculty of Agronomy and Bioengineering, Poznań University of Life Sciences, Poznań, Poland

3 Department of Agricultural Microbiology, Institute of Soil Science and Plant Cultivation, State Research Institute, Puławy, Poland

\section{Introduction}

Herbicides are biologically active compounds that prevent growth of competitive plants in crop cultivation when used in accordance with the manufacturer's instructions, thereby providing the desired plants with better growth and yielding conditions. The large-scale use of herbicides raises great concerns due to their contribution to contamination of the environment, which leads to soil degradation; it is associated 
with the risk of reducing or changing the activity of soil microorganisms [45], which can indirectly affect plant growth and other soil functions. An important role is played by crop plants, in particular their rhizosphere, which is a site of three-way interactions between the plant, roots, and microorganisms [19, 33]. Plants exert an effect on the local microclimate and soil properties as well as soil microbiological diversity. In consequence, they have a significant impact on $\mathrm{C}$ and $\mathrm{N}$ transformations and $\mathrm{CO}_{2}$ emission [55]. Studies show that glyphosate is biodegraded by soil microorganisms. This process requires appropriate conditions, including $\mathrm{C}$ abundance and adequate soil $\mathrm{pH}$ [28]. Bacteria and soil fungi use pesticides as a source of energy by metabolizing them in enzymatic processes [57]. Therefore, the addition of pesticides may cause an increase in enzymatic activity of the soil. The effect of glyphosate on soil microorganisms and its bioavailability and biodegradability depends on microbiome composition as well as soil properties and the type of preparation applied $[6,17]$.

Assessment of changes induced in the soil environment by chemical plant protection agents is highly important to maintain adequate balance of agro-ecosystems and an appropriate level of agricultural production. Monitoring of soil biological indicators is also important for environmental protection and human health. Parameters of microbiological, biochemical, and enzymatic activity have repeatedly been used for monitoring of the condition of soil environments subjected to various types of human pressure [3, 24, 40, 48]. The Biolog EcoPlate ${ }^{\mathrm{TM}}$ method is used for the assessment of the impact of different fertilizers and plant protection products as well as the presence of contaminants on soil microbiological activity [27, 31, 49]. Correlations have been demonstrated between the catabolic potential of microbial communities and other indicators of soil environment quality [39]. Changes in abundance, diversity and activity of soil microorganisms can be used to monitor soil degradation level and to improve the quality of degraded soil $[2,9,24]$.

The large variety of herbicides available in the market requires relevant knowledge of their application, e.g. doses, conditions in which they can be used, and plant susceptibility to herbicides $[4,30]$. Increased use of herbicides carries a risk for ecology and human health [4]. In many countries, the use of glyphosate in agricultural crops has been banned. Poland has not withdrawn glyphosate from the use following the latest scientific data and expert analyses, including the opinion of the Committee for Risk Assessment (RAC) of the European Chemical Agency (ECHA) [21]. In Poland, the use of herbicides from the group organo-phosphates which includes glyphosate amounted to 1159 tons in 2016 [11].

Poland is an important producer of rapeseed. According FAOSTAT [11] the sown acreage in 2017 was 914 thousand hectares, and yield was $29,502 \mathrm{hg} \mathrm{ha}^{-1}$. For comparison in other countries: Germany the sown acreage was $1,308,900$ hectares, and yield was $32,666 \mathrm{hg} \mathrm{ha}^{-1}$; USA the sown acreage was 814 thousand hectares, and yield was $17,492 \mathrm{hg}$ $\mathrm{ha}^{-1}$; Argentina the sown acreage was 25 thousand hectares, and yield was 19,992 $\mathrm{hg} \mathrm{ha}^{-1}$.

A characteristic trait of rapeseed is its long and uneven maturation. The diversity in the level of maturity in rapeseed plantation is associated with the risk of excessive seed moisture or losses caused by mature seed shedding. To ensure uniform seed ripening and to prepare the rapeseed plantation for a one-stage harvest, a desiccation treatment is applied, i.e. plant drying via disturbances in the photosynthetic cycle.

Glyphosate herbicide is one of many chemical agents applied as desiccants available on the market. Glyphosate is a component of many herbicide formulations used for protection of agricultural and horticultural crops worldwide. Investigations conducted in Argentina by Peruzzo et al. [41] showed the presence of glyphosate in water and soil, which indicates the need to study glyphosate-containing formulations, also in terms of their impact on soil microbiological and biochemical activity [58].

The aim of the study was to analyze the response of soil microorganisms to cultivation with using glyphosate of six spring oilseed cultivars.

Literature review shows that herbicides applied in agriculture differently affect soil environment, including microorganism activity which are responsible for soil fertility and health status [35, 36, 43, 48, 57]. There is a need to conduct a comprehensive assessment of the condition of soils treated with chemical plant protection products. Due to the ambiguous research results, and no data on the impact of cultivation different oilseed cultivars the authors conducted a comprehensive study using not only traditional methods applied in soil microbiology, but also a modern method of analyzing microorganism functional diversity.

The authors hypothesized that glyphosate may affect soil microorganisms to varying degrees depending on rapeseed cultivar.

\section{Materials and methods}

\section{Sampling area}

The field experiments were set up in the Experimental Station for Variety Assessment in Głębokie, Kujawsko-Pomorskie Province, Poland (52 $\left.38^{\prime} 41^{\prime \prime} \mathrm{N}, 18^{\circ} 26^{\prime} 18^{\prime \prime} \mathrm{E}\right)$.

The experiment was established on soil from the class of black earths (Mollic Gleysols) formed from sandy loam, which contained $65 \%$ sand fraction $(2-0.5 \mathrm{~mm}), 23 \%$ loam fraction $(0.05-0.002 \mathrm{~mm})$, and $12 \%$ floating particles $(<0.002 \mathrm{~mm})$. The characteristics of the soil used in the experiments are provided in Table S1. 
The experimental treatments (area of $12 \mathrm{~m}^{2}$ ) were established in five replications and sown spring rapeseed (Brassica napus $\mathrm{L}$.) with using six cultivars: Belinda, Markus, $\mathrm{Sw}$ svinto, Tamarin, Feliks, and Clipper (Table S2). They are included in the National Register of Varieties in Poland [20]. Glyphosate was sprayed 7 days before plant harvest. The preparation was used to accelerate and even out the maturity of the rape field and reduce the losses of rape seeds caused by falling off. The technological dose recommended by the manufacturer $\left(3 \mathrm{dm}^{3} \mathrm{ha}^{-1}\right.$ in $100-150 \mathrm{dm}^{3}$ of water) was used. Control - soil without oilseed rape and glyphosate.

\section{Characterisation of the Roundup formulation}

A chemical Roundup 360 SL formulation was used in the field experiment. Its applicable form is a concentrate for making an aqueous solution. In its composition, Roundup 360 SL contains a biologically active compound glyphosate (a compound from the aminophosphonate group). Isopropylamine salt is the active substance contained in the herbicide at a level of $360 \mathrm{~g} / \mathrm{dm}^{3}$ of the formulation. The technological dose recommended by the manufacturer ( 3 $\mathrm{dm}^{3} \cdot \mathrm{ha}^{-1}$ in $100-150 \mathrm{dm}^{3}$ of water) was used.

\section{Soil sampling}

Soil for analysis was collected to sterile containers from the 0-20 cm layer, at the following time points:

\section{I - soon after harvest, \\ II - 1 month after harvest \\ III - 2 months after harvest}

Soil samples were collected randomly from each plot. The average soil sample from each plot consisted of a mixture of five soil cores with a $3 \mathrm{~cm}$ diameter each. Samples were transported to the laboratory in cold conditions at $4{ }^{\circ} \mathrm{C}$. Soil samples were sieved through a $2 \mathrm{~mm}$ sieve, and stored at $4{ }^{\circ} \mathrm{C}$ until analysis.

\section{Microbiological analysis}

Determination of the number of selected groups of bacteria and fungi was performed using the plate method: total number of bacteria on the medium with soil extract [56], total number of fungi on Martin medium [32], and the number of proteolytic bacteria and fungi on the medium with gelatin [56]. The plate method consisted of a series of soil dilutions. Appropriate dilutions were poured into Petri dishes, poured over with medium and incubated at $28{ }^{\circ} \mathrm{C}$. The colonies were counted after 3 days. Colonies with a halo around were considered in case of bacteria and proteolytic fungi.

\section{Biochemical analysis}

The rate of the ammonification process was determined on the basis of $\mathrm{NH}_{4}{ }^{+}$ion content using the Nessler method [37]. Soil samples $(25 \mathrm{~g}$ ) containing $0.1 \%$ asparagine were incubated for 7 days. Subsequently, product concentration resulting from the reaction of the Nessler reagent with $\mathrm{NH}_{4}{ }^{+}$ions was determined colorimetrically in the filtrates $(\lambda=410 \mathrm{~nm})$.

The intensity of the nitrification process was determined on the basis of $\mathrm{NO}_{3}{ }^{-}$content using the brucine method [37]. Soil samples $(25 \mathrm{~g})$ containing $\mathrm{NH}_{4} \mathrm{H}_{2} \mathrm{PO}_{4}$ were incubated for 7 days. Subsequently, product concentration resulting from the reaction of brucine with $\mathrm{NO}_{3}{ }^{-}$ions was determined colorimetrically in the filtrates $(\lambda=470 \mathrm{~nm})$.

Respiratory activity was determined after the addition of $1 \%$ glucose using the titration method of Rühling and Tyler [47]. Soil sample $(20 \mathrm{~g})$ was incubated for $24 \mathrm{~h}$ with $0.2 \mathrm{M}$ $\mathrm{NaOH}$ solution. After the incubation, $\mathrm{BaCl}_{2}$ was added and the excess of unbound sodium hydroxide was titrated with $0.1 \mathrm{HCl}$.

\section{Enzymatic analysis}

Dehydrogenase activity was determined according to the Thalmann [54] method. The activity was determined in $5 \mathrm{~g}$ soil samples using 2,3,5-triphenyl tetrazolium chloride as a substrate, and incubating in $0.2 \mathrm{M}$ tris(hydroxymethyl) aminomethane buffer (Tris- $\mathrm{HCl} \mathrm{pH} \mathrm{7,4)} \mathrm{for} 48 \mathrm{~h}$, at $30{ }^{\circ} \mathrm{C}$. Enzyme activity was determined colorimetrically $(\lambda=485 \mathrm{~nm})$ by measuring the extinction of the produced TPF (triphenylformazan). Protease activity was determined according to the Ladd and Butler [29] method. The activity was determined in $2 \mathrm{~g}$ soil samples using casein as a substrate, and incubating in $0.2 \mathrm{M}$ Tris $-\mathrm{HCl}$ buffer $(\mathrm{pH} 8,0)$ for $1 \mathrm{~h}$ at $50{ }^{\circ} \mathrm{C}$. Enzyme activity was determined colorimetrically $(\lambda=700 \mathrm{~nm})$, based on the amount of tyrosine produced with the Folin reagent. Urease activity was determined according to the Zantua and Bremner [59] method, in $10 \mathrm{~g}$ soil samples using urea solution as a substrate, and incubating for $18 \mathrm{~h}$, at $37{ }^{\circ} \mathrm{C}$. Enzyme activity was determined colorimetrically $(\lambda=410 \mathrm{~nm})$ by measuring the extinction of the mercuric amido-oxyiodide resulting from the reaction of the Nessler reagent with $\mathrm{NH}_{4}{ }^{+}$ions, produced as a result of urea hydrolysis. Acid and alkaline phosphatase activities were determined in $1 \mathrm{~g}$ soil samples using p-nitrophenyl phosphate disodium as a substrate, and incubating in Modified Universal Buffer (pH 6,5 and $\mathrm{pH} 11$ ) for $1 \mathrm{~h}$, at $37{ }^{\circ} \mathrm{C}$ [51]. Enzyme activity was determined colorimetrically $(\lambda=410 \mathrm{~nm})$ by measuring the extinction of p-nitrophenol (PNP) resulting from PNPNa hydrolysis. 


\section{Community level physiological profiling (CLPP) analysis using Biolog EcoPlates}

Community level physiological profiling (CLPP) analysis showing the metabolic potential of soil microbial communities was evaluated using Biolog EcoPlates (Biolog Inc., Hayward, CA, USA). The metabolic potential of soil microbial communities was determined using 31 different carbon sources located in five groups (amines and amides, amino acids, carbohydrate, carboxylic acid, and polymers [42]. The methodology includes the following activities: $1 \mathrm{~g}$ of soil was weighed, transferred to conical flasks holding $99 \mathrm{~cm}^{3}$ of sterile $0.9 \% \mathrm{NaCl}$ each, vortexed for $30 \mathrm{~min}$ at $150 \mathrm{rpm}$ and at $25^{\circ} \mathrm{C}$. In the next step the samples were cooled for $30 \mathrm{~min}$ to $4{ }^{\circ} \mathrm{C}$ and the second step $120 \mathrm{~mm}^{3}$ were transferred to each of the wells in the EcoPlate and incubated in the dark at $28^{\circ} \mathrm{C}$ for $144 \mathrm{~h}$. The experiment was carried out three replications on each soil samples. The results were read every $24 \mathrm{~h}$ on the MicroStation ID system. Reduction of colourless tetrazolium chloride to red formazan $(\lambda=590 \mathrm{~nm})$ was used as the methods to determined extent to which carbon sources were used by soil microbial communities [22]. The most intensive metabolism of carbon substrates was observed after 96-144 h of incubation. The results were expressed as Average Well-Colour Development (AWCD) and Shannon-Weaver $\left(H^{\prime}\right)$ indices.

\section{Statistical analysis}

All analyses were performed in triplicate. Statistical analyzes were performed using STATISTICA.PL (10) (Stat. Soft. Inc. USA). The following analyzes were selected for the statistical evaluation: one way analysis of variance (ANOVA), PC (principal component) analysis, and the Tukey's posthoc HSD test at a significance level $\mathrm{P}<0.05$. The AWCD index was calculated with the formula $\mathrm{AWCD}=\Sigma(\mathrm{C}-\mathrm{R}) / 95$; where $\mathrm{C}=6$ absorbance in each well and $\mathrm{R}=$ absorbance in the control well [14]. The Shannon-Weaver (H') index was evaluated according to Gomez et al. [16].

\section{Results}

\section{Microbiological activity}

The results concerning the development of the studied groups of bacteria and fungi showed significant changes in the level of these microbiological parameters in the soil under all rapeseed cultivars after application of herbicide (Fig. 1). The intensity and direction of these changes varied depending on the time point and plant cultivar.

In the 1 st and 2 nd period of the study, a significant increase in the total bacteria count in the objects with plants was recorded (37.54 - $\left.86.42 \mathrm{cfu} 10^{8} \mathrm{~kg}^{-1}\right)$ (Fig. 1a). The strongest stimulation of this group of microorganisms was found in the soil under the cultivars Belinda $(76.55 \mathrm{cfu}$ $\left.10^{8} \mathrm{~kg}^{-1}\right)$, Sw svinto $\left(86.39 \mathrm{cfu} 10^{8} \mathrm{~kg}^{-1}\right.$ ) and Feliks $\left(86.42 \mathrm{cfu} 10^{8} \mathrm{~kg}^{-1}\right)$. However, the number of these bacteria, recorded in time point II under the Tamarin cultivation was only at a level $20.07 \mathrm{cfu} 10^{8} \mathrm{~kg}^{-1}$ which was similar to the control soil ( $\left.38.58 \mathrm{cfu} 10^{8} \mathrm{~kg}^{-1}\right)$. With time, the stimulating effect disappeared, and even in some objects a decrease in the number of bacteria was noted, which was most pronounced in the soil under the cultivar Clipper (30.02 cfu $\left.10^{8} \mathrm{~kg}^{-1}\right)$.

Rapeseed cultivation with the use of the herbicide had a smaller impact on the development of filamentous fungi (Fig. 1b). Significant changes in the total number of fungi were recorded in all objects only in the second experimental period $\left(54.56-81.22 \mathrm{cfu} 10^{6} \mathrm{~kg}^{-1}\right)$. There was an increase in the number of this group of microorganisms, which was most evident in the soil under the cultivar Belinda (81.22 cfu $10^{6} \mathrm{~kg}^{-1}$ ) and Clipper (76.25 cfu $10^{6} \mathrm{~kg}^{-1}$ ), and the least pronounced under Tamarin $\left(56.14 \mathrm{cfu} 10^{6} \mathrm{~kg}^{-1}\right)$ and Feliks (54.56 cfu $10^{6} \mathrm{~kg}^{-1}$ ). There were generally no significant changes in the development of filamentous fungi at time points I and III. A decrease of this microbiological parameter was found only in the first period in the object under Markus (36.91 cfu $10^{6} \mathrm{~kg}^{-1}$ ) and Clipper (38.95 cfu $10^{6} \mathrm{~kg}^{-1}$ ) cultivation and in the third period under Tamarin cultivation $\left(38.79 \mathrm{cfu} 10^{6} \mathrm{~kg}^{-1}\right)$.

The data presented in Fig. 1c, d shows that the cultivation of rapeseed with the use of Roundup herbicide has significantly contributed to changes in the development of proteolytic bacteria and fungi at all experimental time points. The development of protein-decomposing bacteria (Fig. 1c) was usually weaker in the soil under rapeseed in the first $\left(2.03-3.04 \mathrm{cfu} 10^{8} \mathrm{~kg}^{-1}\right)$ and third $(3.05$ $-5.65 \mathrm{cfu} 10^{8} \mathrm{~kg}^{-1}$ ) period, as compared to the control soil (4.03 and $\left.7.89 \mathrm{cfu} 10^{8} \mathrm{~kg}^{-1}\right)$. This effect was evident in the object under the cultivar Clipper. In contrast to the above-mentioned time points, the development of proteolytic bacteria at time point II was stimulated in all objects $\left(3.07-8.70 \mathrm{cfu} 10^{8} \mathrm{~kg}^{-1}\right)$, with the strongest effect in the soil from the cultivar Clipper. The development of protein-decomposing fungi (Fig. 1d) was clearly inhibited $\left(2.03-4.45 \mathrm{cfu} 10^{6} \mathrm{~kg}^{-1}\right)$, but only in the initial period of the experiment, i.e. in the first period (exception cultivar Clipper). The strongest inhibition of this microbiological parameter was recorded in the soil under the cultivar Feliks. Over time, the negative effect weakened and starting from time point II, a stimulation of the development of these microorganisms was recorded in most objects (3.57 $-8.68 \mathrm{cfu} 10^{6} \mathrm{~kg}^{-1}$ ). This phenomenon was the strongest in objects with the cultivars Feliks $\left(8.47 \mathrm{cfu} 10^{6} \mathrm{~kg}^{-1}\right)$. and Markus $\left(8.68 \mathrm{cfu} 10^{6} \mathrm{~kg}^{-1}\right)$. 
a)

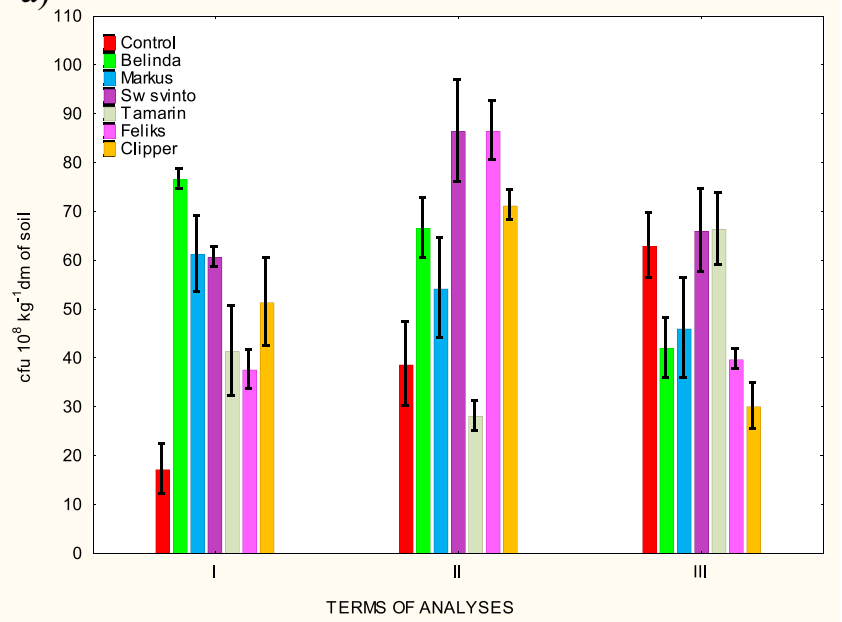

c)

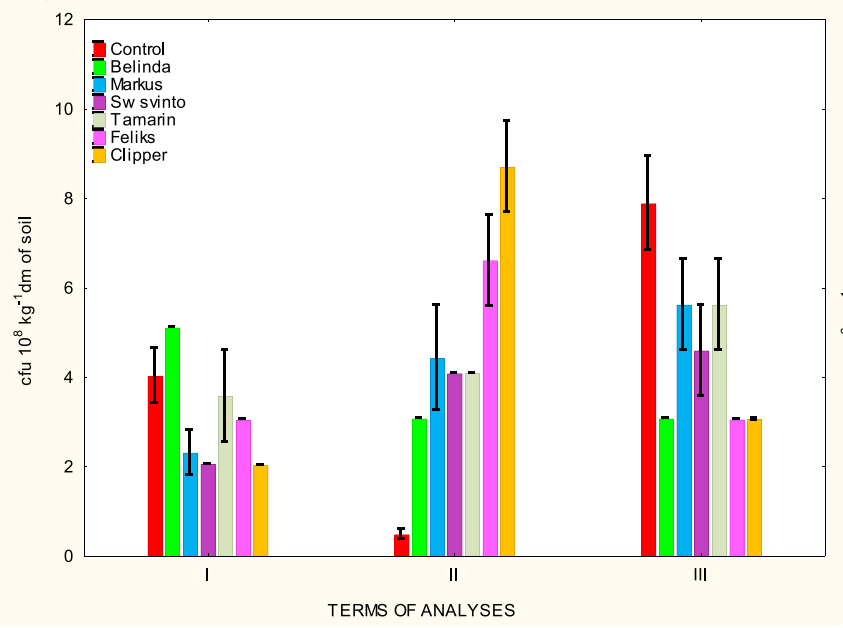

b)

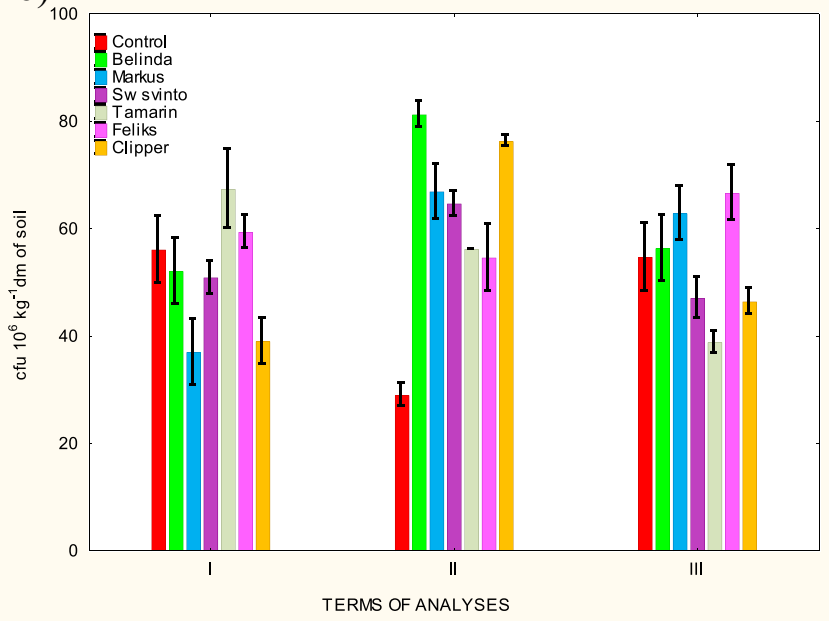

d)

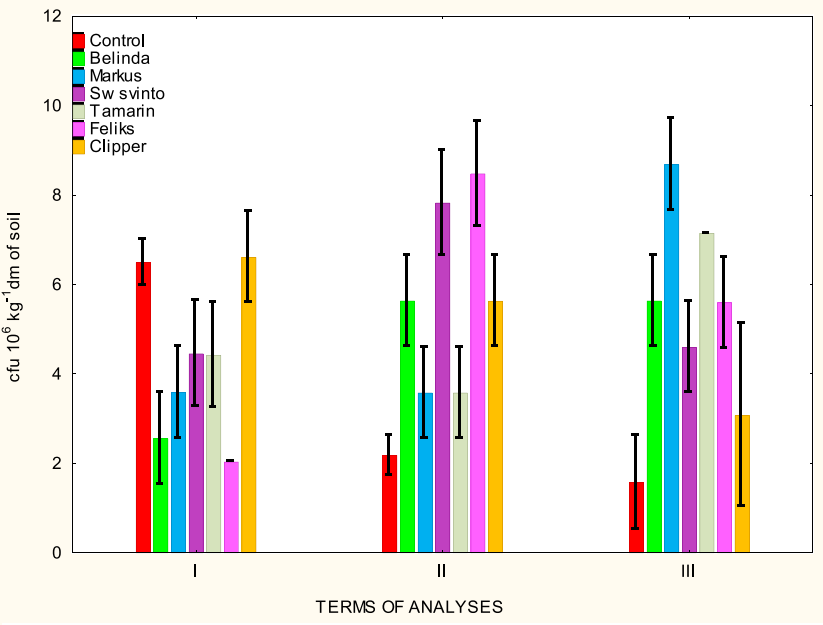

Fig. 1 The numbers of bacteria and fungi in the soil. a) - total bacteria, b) - total fungi, c) - proteolytic bacteria, d)- proteolytic fungi

\section{Biochemical activity}

The data presented in Fig. 2a indicate that the rapeseed cultivation with the herbicide treatment had a significant effect on the respiratory activity in the analyzed soil only in experimental time point I. Stimulation of this biochemical parameter was recorded in all treatments $(83.32-113.56 \mathrm{mg}$ $\left.\mathrm{CO}_{2} \mathrm{~kg}^{-1}\right)$. This effect was most pronounced in the treatments with $\mathrm{Sw}$ svinto $\left(113.56 \mathrm{mg} \mathrm{CO}_{2} \mathrm{~kg}^{-1}\right)$ and Tamarin (112.94 $\mathrm{mg} \mathrm{CO}_{2} \mathrm{~kg}^{-1}$ ) cultivations and the least evident in the treatment with the Feliks cultivar $\left(83.32 \mathrm{mg} \mathrm{CO}_{2} \mathrm{~kg}^{-1}\right)$.

The results of the intensification of biochemical processes associated with nitrogen metabolism in soil, i.e. ammonification and nitrification (Fig. 2b, c), demonstrated that the cultivation of rapeseed treated with glyphosate herbicide significantly disturbed these processes. The effect was more pronounced in the case of the ammonification process (Fig. 2b). The cultivation induced a clear stimulation of nitrogen mineralization at all experimental treatments and time points $\left(146.04-305.93 \mathrm{mg} \mathrm{N}-\mathrm{NH}_{4}\right.$ $\left.\mathrm{kg}^{-1}\right)$. The intensity of this process exhibited a certain dynamics of changes, and the highest values were recorded in time points I and II, especially in the Belinda cultivation treatment (305.93 and $247.73 \mathrm{mg} \mathrm{N}-\mathrm{NH}_{4} \mathrm{~kg}^{-1}$ ).

In contrast to ammonification, changes in nitrification intensity were not as evident and unidirectional (Fig. 2c). At time points I and II, this process in individual treatments was inhibited, stimulated or remain unchanged. Its highest intensity was recorded at time point II in the treatment with the $\mathrm{Sw}$ svinto cultivation $\left(208.26 \mathrm{mg} \mathrm{N}-\mathrm{NO}_{3}\right.$ $\mathrm{kg}^{-1}$ ) and the weakest intensity was detected in both time points in the objects with the cultivar Feliks (87.14 and 
a)

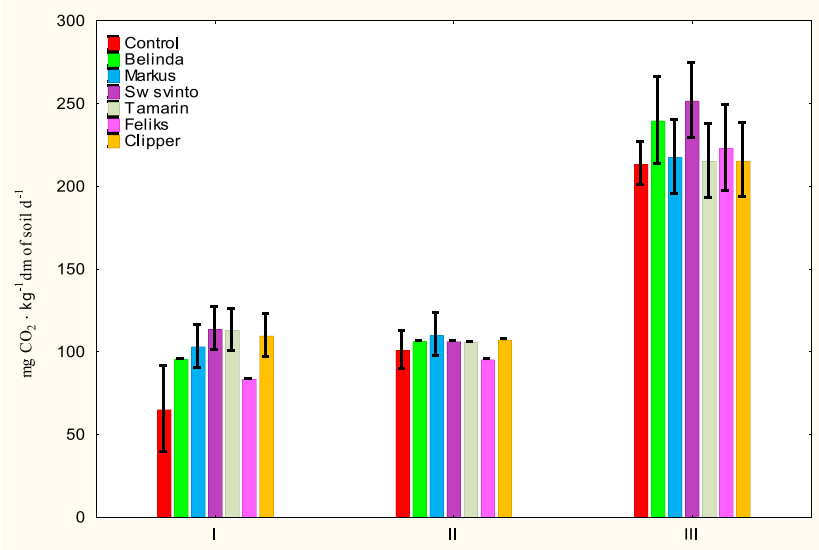

c)

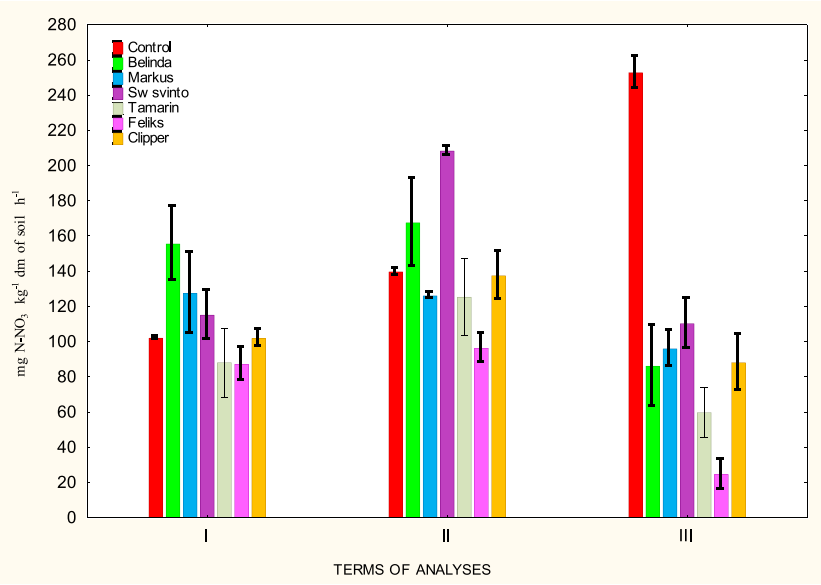

b)

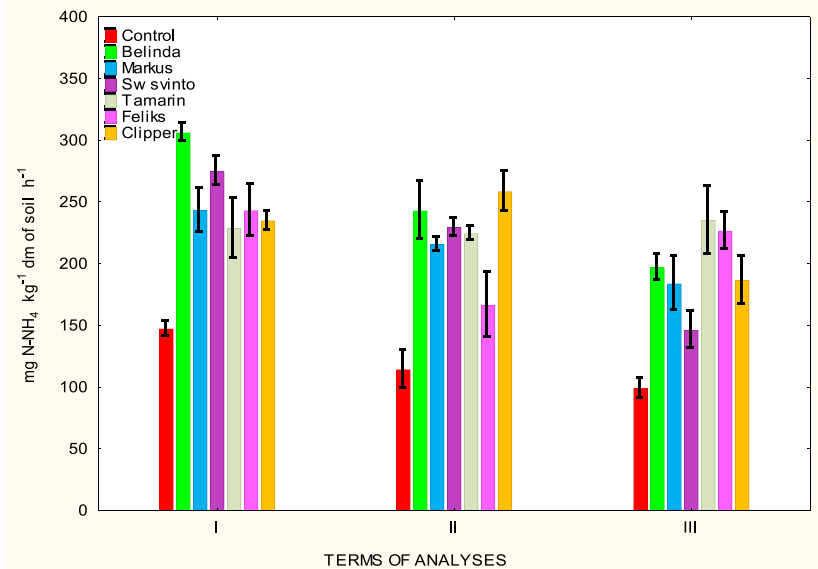

Fig. 2 Biochemical activities in the soil. a) - respiration, b) - ammonification, c) - nitrification

$96.22 \mathrm{mg} \mathrm{N}-\mathrm{NO}_{3} \mathrm{~kg}^{-1}$ ). The effect of the cultivation was clearly directional only at time point III. The intensity of this process was found to decline in all experimental treatments $\left(24.53-110.14 \mathrm{mg} \mathrm{N}-\mathrm{NO}_{3} \mathrm{~kg}^{-1}\right)$ and was most pronounced in the soil sown with the cultivar Feliks (as in other periods).

\section{Enzymatic activity}

Similarly as for microbial abundance and biochemical processes, there were disturbances in the activity of enzymes associated with carbon, nitrogen, and phosphorus cycles in the soil with rapeseed cultivation and herbicide application (Fig. 3). The intensity and trends of these changes depended on the type of the enzyme, period, and rapeseed cultivar.

Dehydrogenase activity was clearly stimulated in all treatments and time points $\left(1.41-44.21 \mathrm{mg}\right.$ TPF $\left.\mathrm{kg}^{-1}\right)$ (Fig. 3a). The highest values of this parameter were noted in the soil sown with the cultivars Belinda and Markus. The lowest dehydrogenase activity was detected in the soil with
Tamarin cultivation; its value at time point II was similar to that recorded in the control soil $\left(0,40 \mathrm{mg}\right.$ TPF $\left.\mathrm{kg}^{-1}\right)$.

Among the analyzed enzymes, protease and urease activities exhibited the lowest changes (Fig. 3b, c). There was a pronounced effect of the plant and herbicide on the activity of these enzymatic parameters in all treatments only in the initial period of the study (protease $6.08-12.35 \mathrm{mg}$ tyrosine $\mathrm{kg}^{-1}$; urease $10.64-15.59 \mathrm{mg} \mathrm{N}-\mathrm{NH}_{4} \mathrm{~kg}^{-1}$ ). This effect was generally positive. There was a decrease in proteolytic activity only in the treatment with Clipper cultivation $(1.74 \mathrm{mg}$ tyrosine $\mathrm{kg}^{-1}$ ). Over time, the positive effect declined and was noticeable only in certain treatments.

The activity of enzymes associated with phosphorus transformation, i.e. acid and alkaline phosphatases (Fig. 3d, e), showed clear changes in all treatments. The plant cultivation exerted a beneficial impact on both these parameters almost in the whole experimental period. The activity of acid phosphatase was inhibited in all treatments only at time point III $\left(17.05-30.40 \mathrm{mg}\right.$ PNP kg$\left.{ }^{-1}\right)$. The beneficial effect was more pronounced in the case of alkaline phosphatase 
a)

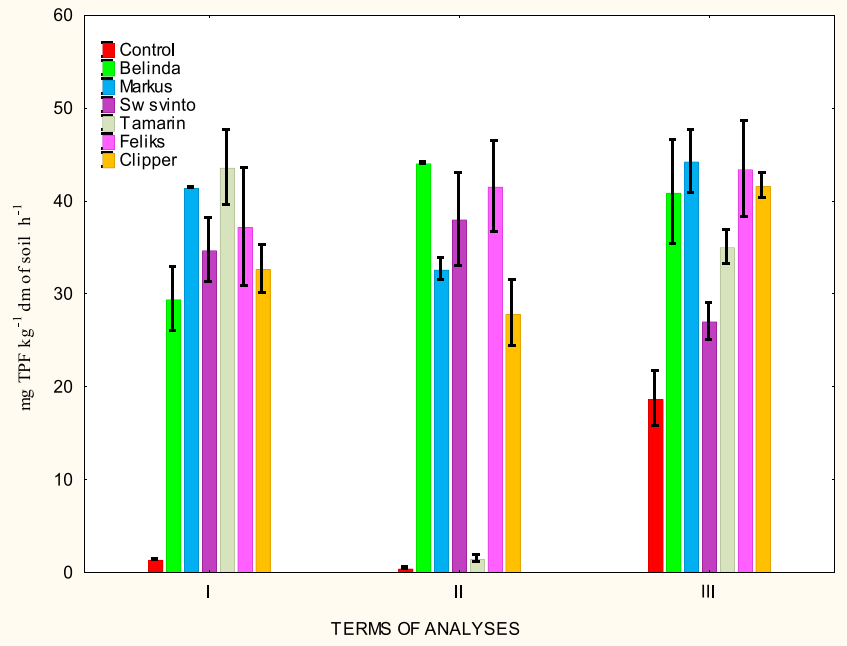

c)

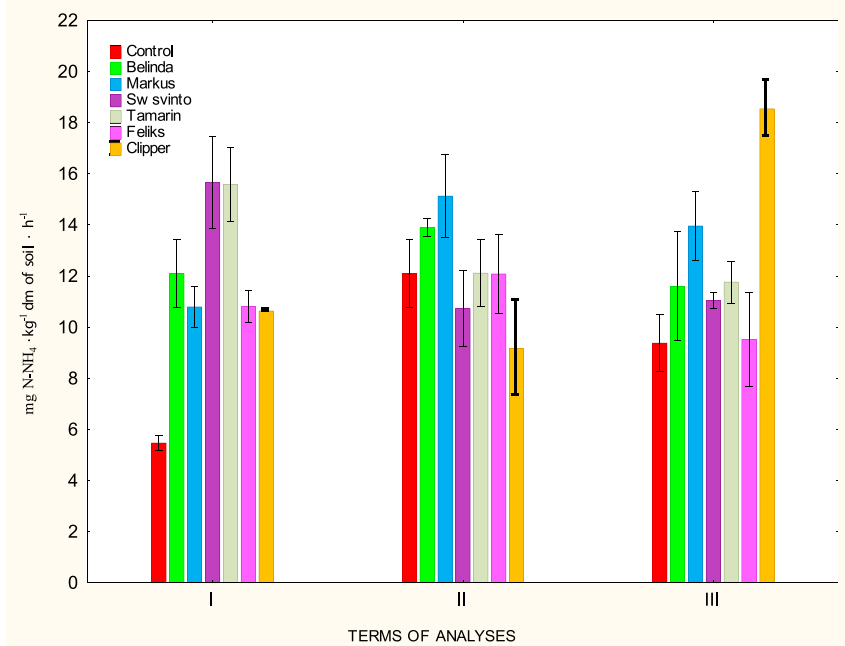

e)

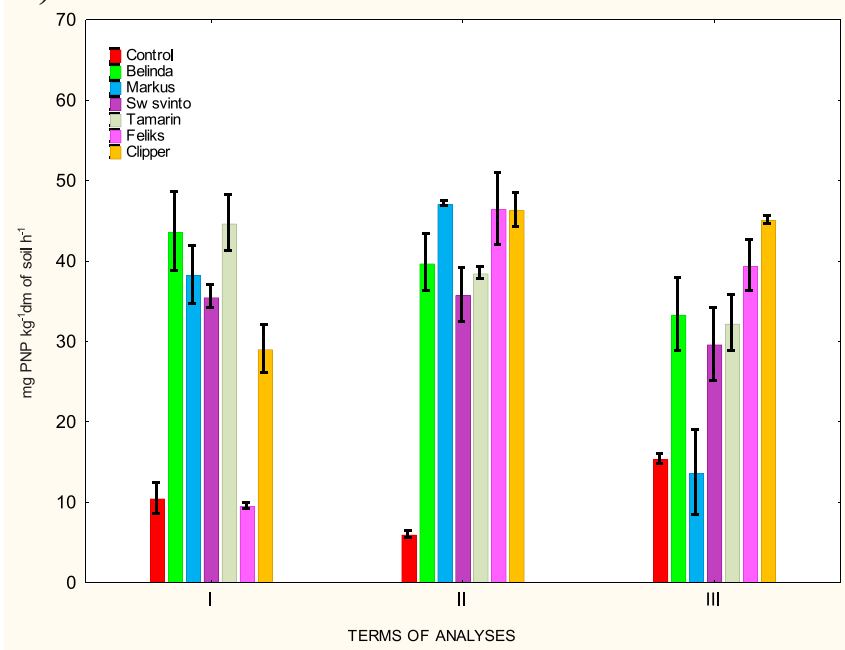

b)

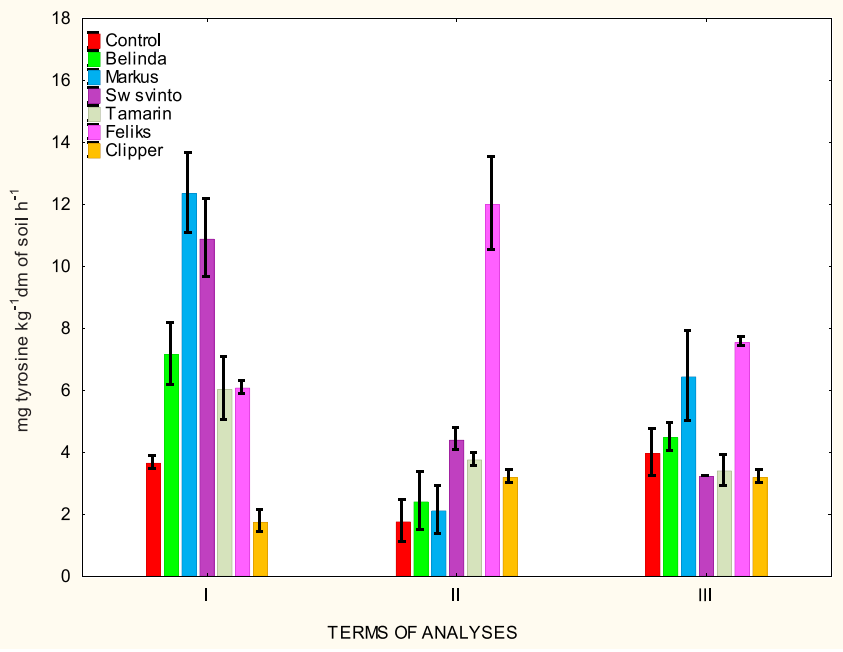

d)

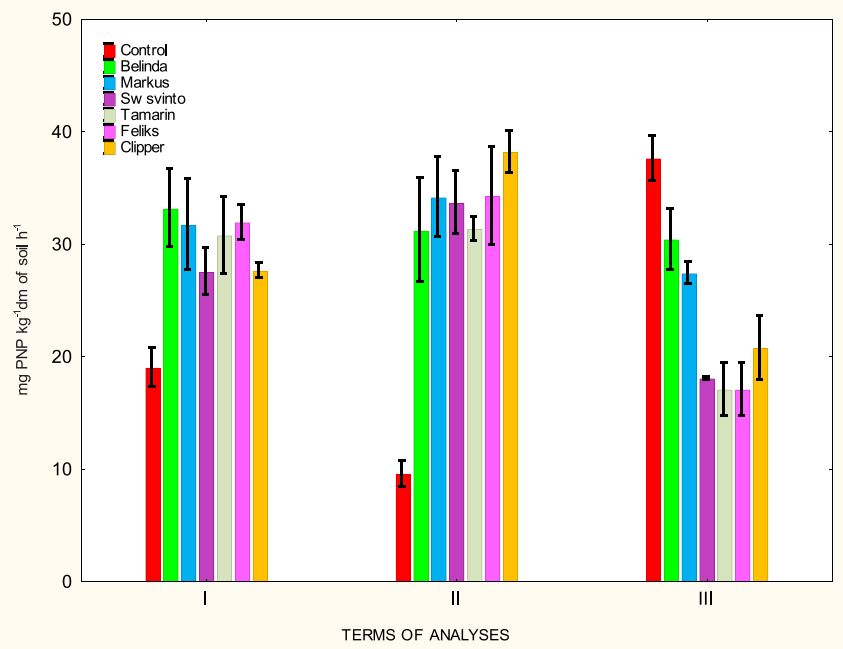

Fig. 3 Enzymatic activities in the soil. a) - dehydrogenases, b) - protease, c) - urease, d) - acid phosphatase, e) - alkaline phosphatase 
(28.99 - $47.04 \mathrm{mg} \mathrm{PNP} \mathrm{kg}{ }^{-1}$ ). The highest values of the activity of both phosphatases were noted in the soil with Clipper and Feliks cultivations.

\section{Biolog EcoPlates}

The values of the average well-color development (AWCD) index in the Biolog EcoPlate incubated from 0 to $144 \mathrm{~h}$ are presented in Fig. 4. The AWCD index increased proportionally to $72-144 \mathrm{~h}$; therefore, $120 \mathrm{~h}$ were selected as the most optimal time for calculating the biodiversity index (Table S3).

There were statistically significant differences in the AWCD value in soil with different rapeseed cultivars (Table S3). The highest AWCD value was found for the soil with Belinda and Tamarin cultivations, whereas the soil sown with the cultivars Markus, Feliks, and Clipper was characterized by the lowest AWCD value. The value of the Shannon index $\left(H^{\prime}\right)$ also increased proportionally to the sample incubation time. The highest values of the Shannon biodiversity index were recorded at $96-144 \mathrm{~h}$ of sample incubation. There were no statistically significant differences in the Shannon index value in the soil with individual rapeseed cultivars during the 120-h incubation of samples (Table S3).

The effect of different plants on the catabolic diversity of microbial communities was evaluated by substrate utilization in the Biolog EcoPlate incubated for 0-144 h (Fig. 5). The utilization of the individual groups of compounds was proportional to the incubation time. The highest values of absorbance readings were recorded at 96-144 h. Carbohydrates and carboxylic acids were most easily utilized by the microorganisms. The lowest absorbance values were observed for the utilization of amines and amides as well as polymers (Fig. 5).

There were statistically significant differences in the microbial utilization of individual compound groups in soils sown with different rapeseed cultivars (Fig. 6). During the $120 \mathrm{~h}$ incubation of Biolog EcoPlates, the highest metabolic activity of microorganisms utilizing carboxylic acids was detected in the soil with the cultivation of Belinda, Sw svinto, and Clipper. In terms of utilization of carbohydrates as a carbon source, the highest metabolic activity of microorganisms was observed in the soil sown with the cultivars Markus and Feliks. The greatest variation among the cultivars was observed in the utilization of polymers as a carbon source. In this group, the highest activity was noted for the cultivars Markus and Feliks.

Figure 7 presents a thermal map of the utilization of 31 compounds in the soil for each rapeseed cultivar during incubating the plates for $120 \mathrm{~h}$. The soil collected from cultivations of the cultivars Belinda, Tamarin, and $\mathrm{Sw}$ svinto was characterized by the highest microbial activity. a)

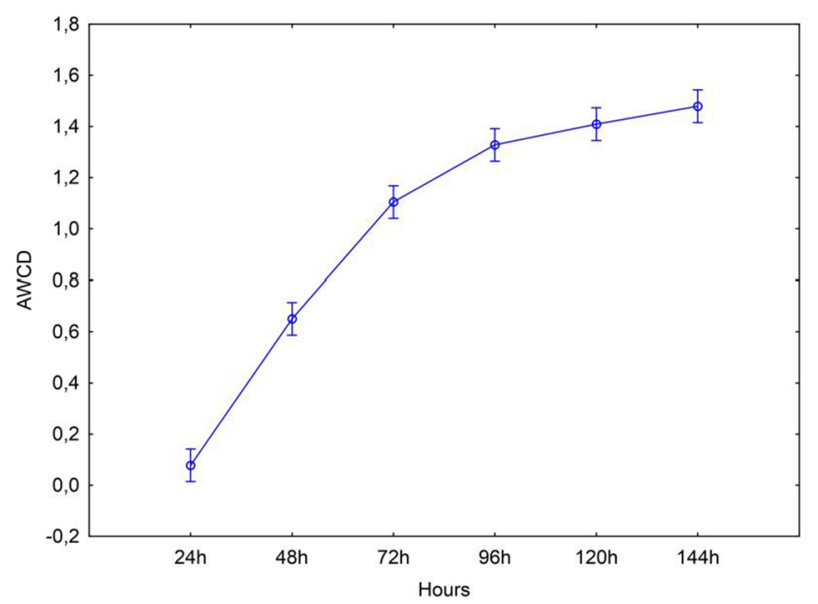

b).

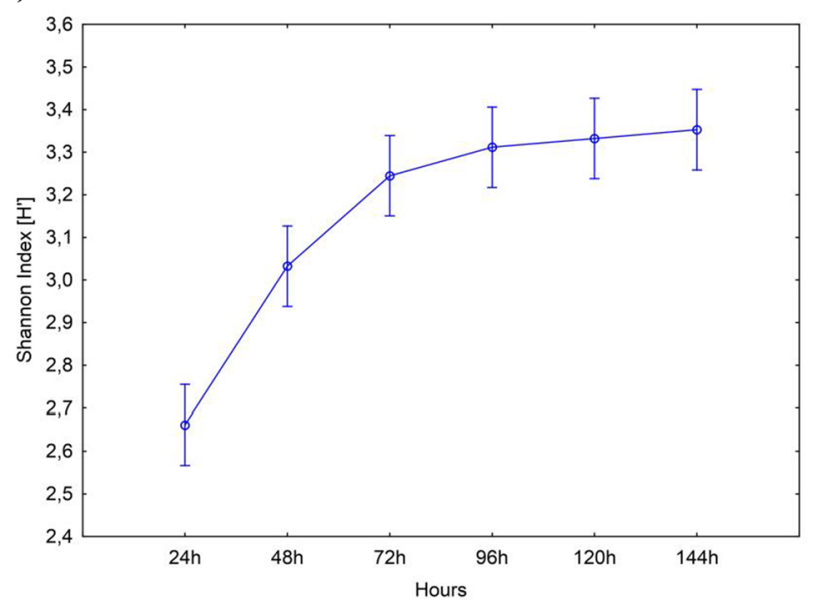

Fig. 4 One-way analysis of variance (ANOVA) showing the changes of: a) AWCD index and b) Shannon index from time; $P<0,001$. Vertical bars represent $95 \%$ confidence intervals

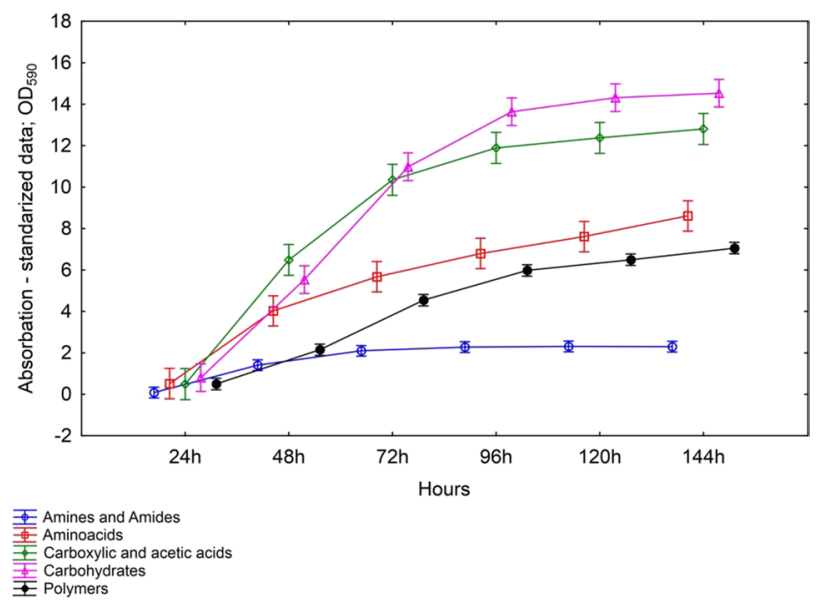

Fig. 5 Effect of different cultivars on microbial community catabolic diversity as evaluated by substrate utilization in the Biolog EcoPlate incubated for $144 \mathrm{~h}$ 
a)

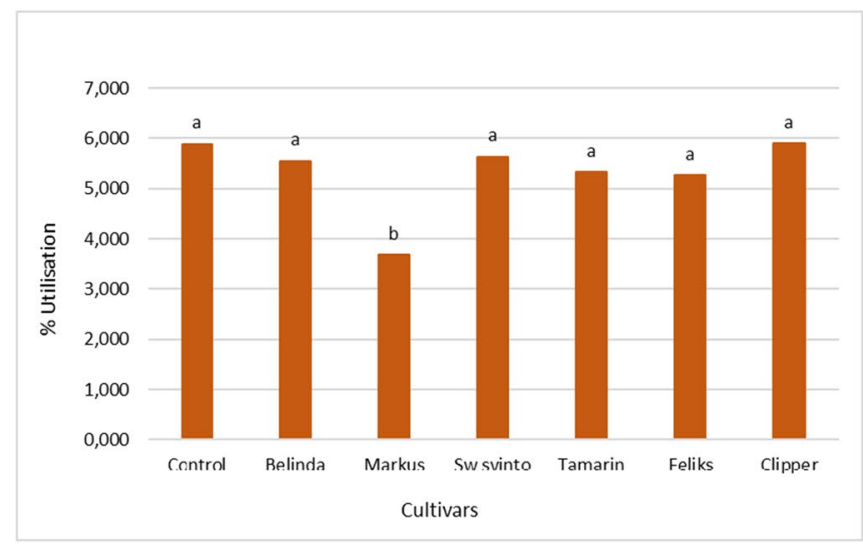

c)

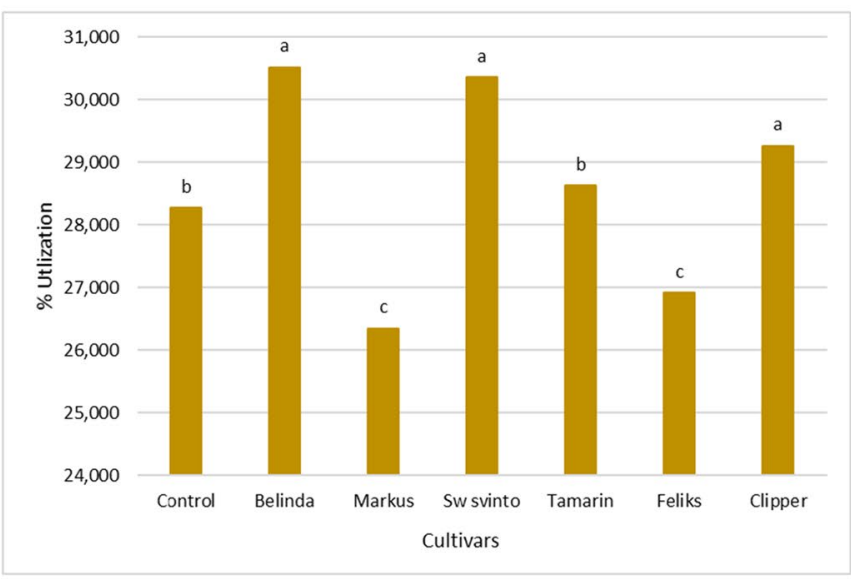

e)

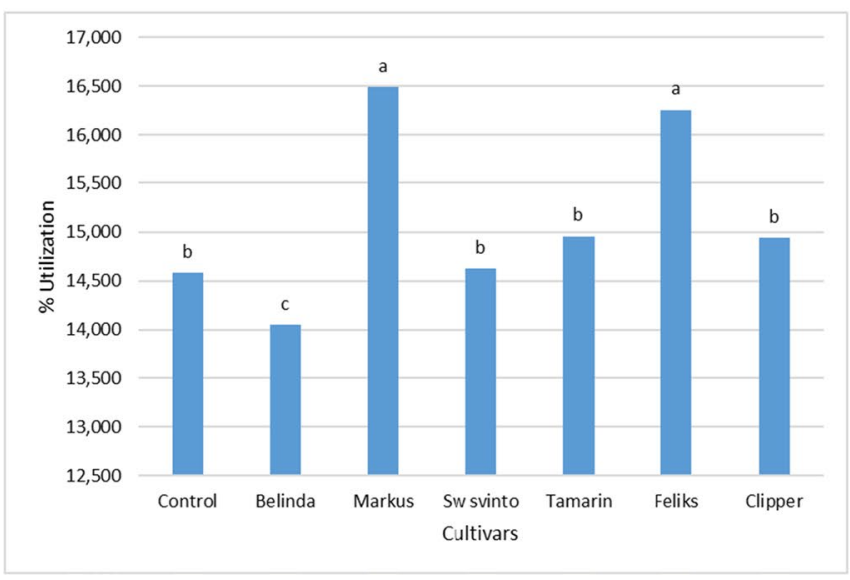

Fig. 6 Effect of different cultivars on microbial community catabolic diversity as evaluated by substrate utilization in the Biolog EcoPlate incubated for $120 \mathrm{~h}$. Vertical bars represent the standard error of the mean. Treatment means separated by different letters are significantly b)

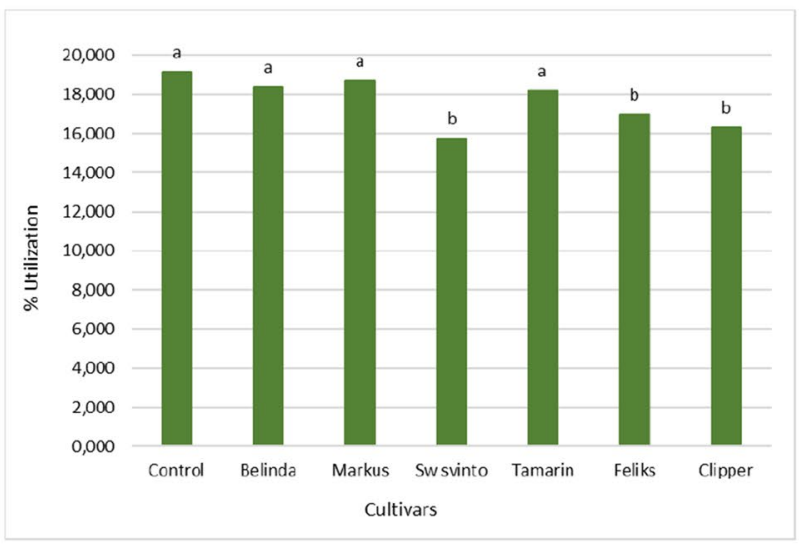

d)

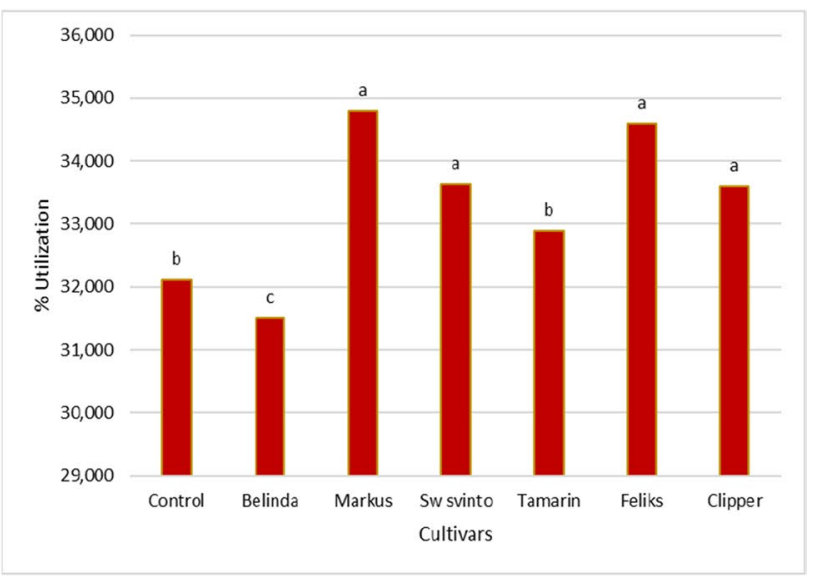

differ (Tukey's mean separation test, $P<0.05$ ). a) amines and amides, b) aminoacids, c) carboxylic and acetic acids, d) carbohydrates, e) polymers 
Soil sampled from the cultivation of Belinda, Tamarin, and $\mathrm{Sw}$ svinto and control soil were characterized by the highest correlations between the rapeseed cultivars and the biological activity assessed on the basis of the utilization of carbon sources during the $120 \mathrm{~h}$ incubation of Biolog EcoPlates (Figure S1a). The principal component analysis (PCA) revealed strong correlations between soil biological activity parameters and indicators of the activity obtained using the Biolog method. There were strong positive correlations between the number of fungi and the utilization of carbohydrates and polymers by microorganisms. In turn, amino acid utilization correlated positively with the number of all and proteolytic bacteria and acid phosphatase activity (Figure S1b).

\section{Discussion}

One of the many important roles played by microorganisms is their involvement in degradation and detoxification of various types of soil contaminants [10], e.g. chemical plant protection agents (pesticides). As shown by Upadhyay and Dutt [57], fungi, bacteria, and actinomycetes exhibit varied ability to transform and degrade pesticides. Among these microorganisms, the greatest ability to degrade xenobiotics is attributed to fungi due to their high resistance to adverse environmental conditions. Gianfreda and Rao [15] have argued that fungi mostly contribute to biotransformation of pesticides and xenobiotics in the soil by changing the structure of compounds, and thus contributing to the elimination of their toxicity. Transformed pesticides are released into the soil and are further degraded by bacteria. Therefore, soil microorganisms prevent the accumulation of these substances in the soil environment [52].

The intensity of pesticide degradation by soil microorganisms largely depends on organic matter content and climatic conditions, e.g. moisture and temperature. Humidity and temperature influence the growth of bacteria and fungi and, consequently, their activity [50]. The seasonal changes in the number of bacteria and, to a lesser extent, fungi in the control soil could be caused by fluctuations in temperature and humidity under field conditions. Stronger changes in the case of bacteria probably resulted from the greater sensitivity of these microorganisms. Stanaszek-Tomal [50] shows the high resistance of fungi to unfavorable conditions. As emphasised by many authors [7, 18, 38], an increase in soil organic matter content (crop residues), which is a source of nutrients for microorganisms, leads to an increase in microbial abundance. Sebiomo et al. [48] studied the influence of, among others, glyphosate on the populations of bacteria, actinomyces and fungi in a dose recommended by the manufacturer and found its negative impact on these microbiological parameters. In addition, organic matter contributes to herbicide immobilization in soil [12]. The present analysis of the number of soil bacteria after glyphosate formulation application in the individual experimental treatments demonstrated that the changes were dependent on rapeseed cultivar and duration of formulation treatment. This suggests a
Fig. 7 HeatMaps for the carbon utilization patterns of the substrates located only on the Biolog EcoPlates date incubated for $120 \mathrm{~h}$ from soil samples

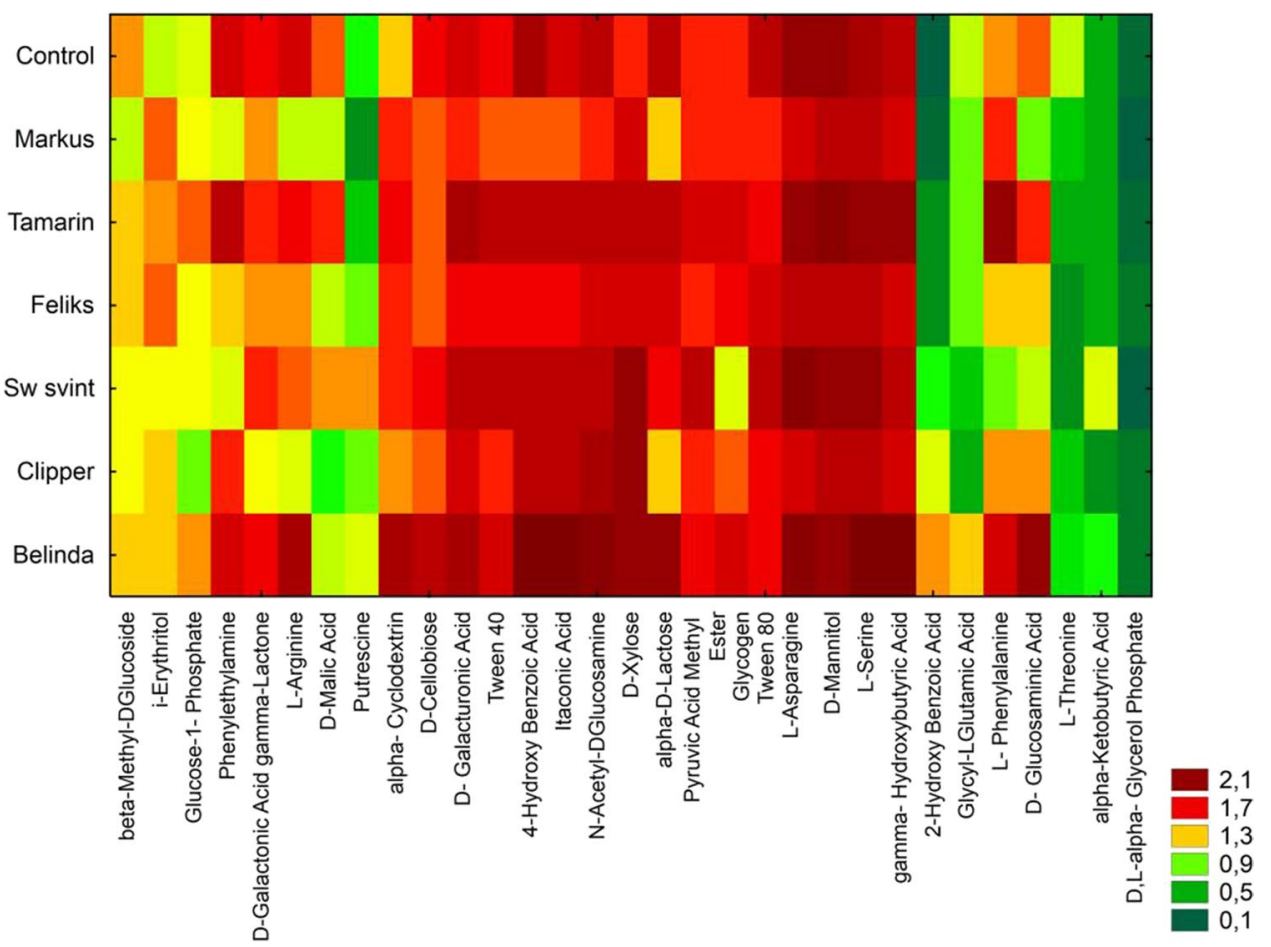


significant influence of rapeseed cultivars on these microbiological parameters.

The results of the analysis of fungal abundance in the experimental soil indicated that glyphosate significantly stimulated the growth in this microbial group in the presence of different rapeseed cultivars. Fungi, next to bacteria and actinomycetes, have the capability to use pesticides as a source of energy and C [57] Carbon-rich root secretions may have also exerted an impact on the growth of this microbial group [33]. The number of fungi increased, which may suggest that fungi are able to utilize glyphosate as an energy source. As demonstrated by Benslamaand and Boulahrouf [5], glyphosate had no negative effect on microbial activity and could improve soil quality. The authors underlined the necessity of further investigations to assess the risk of long-term application of glyphosate in various regions. Sebiomo et al. [48] investigated the effect of various herbicides, including glyphosate, on soil microbial populations. Their experiments showed that microorganisms were able to utilize herbicides as a carbon source, as evidenced by the increase in bacterial and fungal populations after glyphosate application. Partoazar et al. [40] found a significantly larger population of heterotrophic bacteria in soil contaminated with glyphosate for a longer period (12 years) than in soil treated with the formulation for 1 month or 1 day or in noncontaminated soil. Ratcliff et al. [46] demonstrated that a high glyphosate concentration stimulated microbial growth, whereas the field dose of the formulation did not induce major changes in microbial population.

A common indicator in the assessment of the soil environment status is respiratory activity, which reveals potential disturbances in carbon transformation processes induced by adverse effects of pesticides and other xenobiotics. The present field experiments did not demonstrate a negative effect on the respiratory activity of soil sown with different spring rapeseed cultivars. In the initial phase of the experiment, respiratory activity in the experimental treatments with rapeseed cultivation was higher than in the control soil. In the last period of the analyses, rapeseed cultivars did not show a significant impact on respiratory activity. Similar results were reported by other authors, e.g. Kara et al. [25].

Enzymatic activities are commonly recognized as sensitive indicators informing early about the dynamics of organic matter metabolism, circulation of nutrients, as well as about stress and restoration processes occurring in soil [8].

Soil dehydrogenases are regarded as a good indicator of total microbial activity and can be used to assess the effects of herbicide application on soil microflora [48].

Glyphosate applied in the present study significantly stimulated the activity of dehydrogenases in the soil with spring rapeseed in the initial and final periods of the experiment. The only exception was the soil with the cultivar Tamarin, in which dehydrogenase activity decreased to $1.410 \mathrm{mg}$ TPF $\mathrm{kg}^{-1}$ day $^{-1}$ at time point II.

Ranjith et al. [45] investigated soil dehydrogenase activity after glyphosate application in 11 different concentrations (from 0 to $2000 \mathrm{ppm}$ ). The authors observed higher dehydrogenase activity in the final stage of the experiment, which they explained by the ability of microorganisms to utilize less complex glyphosate-derived compounds formed after degradation carried out by specialized microbial groups. Sebiomo et al. [48] found in the study on the effect of four herbicides on dehydrogenase activity that glyphosate-treated soil exhibited the highest dehydrogenase activity in comparison to other herbicides used in the experiment. The authors concluded that this could be related to an increase in microorganism population and their ability to utilize this herbicide as a carbon source. A study carried out by Partoazar et al. [40] demonstrated that dehydrogenase activity increased substantially over time compared to control.

Protease responds to pesticides present in soil. Its activity in soil can indicate the biological ability of enzymatic transformation of the substrate. One of the most important functions of the enzyme is its involvement in mineralization of organic nitrogen compounds, which affects the availability of this element to plants [26]. The experiments with pesticides of the latter author showed an increase in soil proteolytic activity induced by low doses of these formulations. Ramudu et al. [44] found an increase in protease activity caused by the application of field doses of fungicides. Significantly higher protease activity in soils with the cultivation of spring rapeseed cultivars, especially Markus, Clipper, and Feliks, was also found in the present study.

Urease is another enzyme involved in nitrogen transformation in soil that also responds to soil contamination. As shown by Ramudu et al. [44], a decline in the activity of this enzyme in soil may be related to a decrease in ion concentration and $\mathrm{pH}$ as well as pesticide contamination. In the present study, urease activity was influenced by the herbicide applied and rapeseed cultivar.

Nitrogen is one of the most important biogenic elements in nature, and ammonification and nitrification are processes indicating its transformation in soil. These processes not only play an important role in the circulation of this element in soil, but are also regarded as an important indicator of soil biological activity. Muñoz-Leoz et al. [34] found that microorganisms involved in nitrogen circulation are the most sensitive soil microorganisms to soil contamination with plant protection products. In their study, Kara et al. [25] observed that triazine herbicide (active substance: $35 \%$ terbutryn, $15 \%$ terbuthylazine) caused an increase or a decrease in the intensity of the ammonification process depending on soil $\mathrm{pH}$. Herbicide applied in the present study had a stimulating effect on the ammonification process, and differences in its intensity depended on 
the spring rapeseed cultivar. The intensity of nitrification in the field experiment exhibited significant periodic fluctuations. Rapeseed cultivars had an effect on differences in nitrification intensity. Noteworthy is the low value of this indicator at time point II of the analyses in the soil sampled from all treatments with the cultivation of rapeseed cultivars. In this period, the intensity of ammonification in the soil sown with the analyzed rapeseed cultivars was significantly higher than in the control soil.

The activity of enzymes involved in phosphorus transformation in soil can also be used to assess the impact of pesticides on changes in the soil environment. The current study demonstrated that acid and alkaline phosphatase activity at time points I and II was significantly higher in the soil from treatments with rapeseed cultivars than in control. In the final period of research, there was a decline in acid phosphatase activity in treatments with six spring rapeseed cultivars in comparison to the control soil (Fig. 3). Alkaline phosphatase activity during this study period was statistically significantly higher than in control.

The analysis of catabolism of carbon sources by soil microorganisms revealed the highest level of utilization of substrates from the carbohydrate group by all rapeseed cultivars and the lowest level in the group of amines and amides (Figure S1). Similar results on the utilization of amines and amides as well as carbohydrates by soil microorganisms were reported by other researchers $[13,53]$.

Literature data [23] demonstrate that cultivated plants have a greater impact on the diversity of microbial communities than soil type. Similarly, Cardozo Junior et al. [9] showed that catabolic activity was dependent on the plant cover. The results obtained in the present experiment supported this theory, as there were statistically significant differences in the AWCD values (Table S2) and in the level of substrate group utilization (Figure S1) between rapeseed cultivars.

We found correlations between different soil quality parameters and microorganism catabolic potential, which is consistent with literature data [1].

\section{Conclusions}

The rapeseed cultivation using herbicide showed significant changes in the growth of the analyzed groups of bacteria and fungi and their biochemical and enzymatic activities in the soil. The nature and intensity of the impact on activity parameters depended on the period and plant cultivar. It should be noted that the cultivar Clipper turned out to be the least favorable plant for most of the analyzed microbiological activities.
Respiratory activity and the ammonification process were stimulated in treatments with rapeseed cultivars treated with the herbicide. The cultivar Sw svinto had a positive effect on the intensity of respiration and nitrification, whereas the cultivar Feliks exerted the least beneficial impact on these parameters. The highest increase in the ammonification process was recorded for soil from the cultivation of the cultivar Belinda.

There was a generally positive effect of rapeseed cultivars treated with the herbicide on enzymatic activity. In the case of dehydrogenase activity, this effect persisted throughout the research period and was particularly pronounced in Belinda and Markus cultivation treatments. The activity of protease and urease underwent the lowest changes. Phosphatase activity was intensified in the soil sampled from treatments with rapeseed cultivars. The cultivars Clipper and Feliks were found to exert the most beneficial effects on the activity of both acid and alkaline phosphatases.

The cultivars Belinda, Tamarin, and Sw svinto exerted the most beneficial effect on the catabolism of soil microorganisms. Simultaneously, soil originating from the treatment with the Belinda cultivation exhibited the greatest microbial diversity, as evidenced by the Shannon index $\left(H^{\prime}\right)$. The cultivar Markus was characterized by the least favorable effect on microbial metabolism.

The decrease in microbial activity is one of the causes of soil degradation. Cultivation of specific plant varieties that reduce the negative effect of herbicides used in agriculture may be one of the methods to prevent soil degradation. In our research, Belinda turned out to be a cultivar, under the cultivation of which an increase in the activity of microorganisms was recorded most frequently compared to soil not sown with rapeseed.

Supplementary Information The online version contains supplementary material available at https://doi.org/10.1007/s40201-021-00753-3.

Acknowledgements This work was financed by the Ministry of Science and Higher Education, Poland under the research grant No. N N305 410 538. The research was conducted within the frames of Task 1.4. Multi - Annual Programme IUNG - PIB (2016-2020).

\section{Declarations}

Conflict of interest The authors declare no conflict of interest.

Open Access This article is licensed under a Creative Commons Attribution 4.0 International License, which permits use, sharing, adaptation, distribution and reproduction in any medium or format, as long as you give appropriate credit to the original author(s) and the source, provide a link to the Creative Commons licence, and indicate if changes were made. The images or other third party material in this article are included in the article's Creative Commons licence, unless indicated otherwise in a credit line to the material. If material is not included in the article's Creative Commons licence and your intended use is not 
permitted by statutory regulation or exceeds the permitted use, you will need to obtain permission directly from the copyright holder. To view a copy of this licence, visit http://creativecommons.org/licenses/by/4.0/.

\section{References}

1. Adams TC, Brye KR, Savin MC, Lee JA, Gbur EE. Microbial carbon substrate utilization differences among high- and averageyield soybean areas. Agriculture. 2017;7:1-15. https://doi.org/10. 3390/agriculture7060048.

2. Armas-Herrera CM, Martí C, Badía D, Ortiz-Perpiñ O, GironaGarcía A, Mora JL. Short-term and midterm evolution of topsoil organic matterand biological properties after prescribed burning for pasturerecovery (Tella, Central Pyrenees, Spain). Land Degrad Dev. 2018;29:1545-54. https://doi.org/10.1002/ldr.2937.

3. Bautista-Cruz A, Leyva-Pablo T, León-Gonzále F, Zornoza R, Martínez-Gallegos V, Fuentes-Ponce M, Rodríguez-Sánchez L. Cultivation of Opuntia ficus-indica under different soil management practices: A possible sustainable agricultural system to promote soil carbon sequestration and increase soil microbial biomass and activity. Land Degrad Dev. 2017;29:38-46. https://doi.org/10. 1002/ldr.2834.

4. Benbrook CM. Trends in glyphosate herbicide use in the United States and globally. Environ Sci Eur. 2016;28:3. https://doi.org/ 10.1186/s12302-016-0070-0.

5. Benslamaand $\mathrm{O}$, Boulahrouf $\mathrm{A}$. Isolation and characterization of glyphosate-degrading bacteria from different soils of Algeria. Afr J Microbiol Res. 2013;7:5587-95. https://doi.org/10.5897/AJMR2 013.6080.

6. Binh Nguyen D, Rose MT, Rose TJ, van Zwieten L. Effect of glyphosate and a commercial formulation on soil functionality assessed by substrate induced respiration and enzyme activity. Eur J Soil Biol. 2018;85:n64-72. https://doi.org/10.1016/j.ejsobi. 2018.01.004.

7. Bridges KM, Fultz LM, Alison MW, Han KJ, Macoon B, Pitman WD. Quantifying soil health in a topographically diverse warmseason perennialpasture over-seeded with a mix of cool-season annuals. Agric Ecosys Environ. 2019;282:58-68. https://doi.org/ 10.1016/j.agee.2019.05.016.

8. Burns RG, DeForest JL, Marxsen J, Sinsabaugh RL, Stromberger ME, Wallenstein MD, Weintraub MN, Zoppini A. Soil enzymes in a changing environment: current knowledge and future directions. Soil Biol Biochem. 2013;58:216-34. https://doi.org/10.1016/j. soilbio.2012.11.009.

9. Cardozo Junior FM, Carneiro RFV, Rocha SMB, Nunes LAPL, Santos VM, dos Feitoza LL, Araújo ASF. The impact of pasture systems on soil microbial biomass and community-level physiological profiles. Land Degrad Dev. 2018;29:284-91. https://doi. org/10.1002/ldr.2565.

10. Chowdhury A, Pradhan S, Saha M, Sanyal N. Impact of pesticides on soil microbiological parameters and possible bioremediation strategies. Indian J Microbiol. 2008;48:114-27. https://doi.org/ 10.1007/s12088-008-0011-8.

11. FAOSTAT (2019) http//faostat.fao.org

12 Flores C, Morgante V, González M, Navida R, Seegert M. Adsorption studies of the herbicide simazine in agricultural soils of the Aconcagua valley, central Chile. Chemosphere. 2009;74:15441549. https://doi.org/10.1016/j.chemosphere.2008. 10.060 .

13. Furtak K, Gawryjołek K, Gajda AM, Gałąza A. Effects of maize and winter wheat grown in different cultivation techniques on biological activity of soil. Plant Soil Environ. 2017;63:449-54. https://doi.org/10.17221/486/2017-PSE.

14. Garland JL, Mills AL. Classification and characterization of heterotrophic microbial communities on the basis of patterns of community-level sole-carbon-source utilization. Appl Environ Microbiol. 1991;57:2351-9.

15. Gianfreda L, Rao M. Potential of extra cellular enzymes in remediation of polluted soils: a review. Enzyme Microb Tech. 2004;35:339-54. https://doi.org/10.1016/j.enzmictec.2004.05. 006.

16 Gomez E, Garland J, Conti M. Reproducibility in the response of soil bacterial community-level physiological profiles from a land use intensification gradient. Appl Soil Ecol. 2004;26:21-30. https://doi.org/10.1016/j.apsoil.2003.10.007.

17. Guijarro KH, Aparicio V, De Gerónimo E, Castellote M, Figuerola EL, Costa JL, Erijman L. Soil microbial communities and glyphosate decay in soils with different herbicide application history. Sci Total Environ. 2018;634:974-82. https://doi.org/10.1016/j.scito tenv.2018.03.393.

18. Güsewell S, Gessner MO. N: P ratios influence litter decomposition and colonization by fungi and bacteria in microcosms. Funct Ecol. 2009;23:211-9. https://doi.org/10.1111/j.1365-2435.2008. 01478.x.

19. Haichar FZ, Santaella C, Heulin T, Achouak W. Root exudates mediated interactions belowground. Soil Biol Biochem. 2014;77:69-80. https://doi.org/10.1016/j.soilbio.2014.06.017.

20. https://agro-technika.pl/archiwa/rzepak-jary-odmiany-i-uprawa/

21. http://europa.eu/rapid/press-release_IP-17-5191_en.htm

22. Islam MR, Chauhan PS, Kim Y, Kim M, Sa T. Community level functional diversity and enzyme activities in paddy soils under different long-term fertilizer management practices. Biol Fertil Soils. 2011;47:599-604. https://doi.org/10.1007/s00374-010-0524-2.

23. Jesus EC, Liang C, Quensen JF, Suslawati E, Jackson RD, Balser TC, Tiedje JM. Influence of corn, switchgrass, and prairie cropping systems on soil microbial communities on the upper Midwest of the United States. Glob Change Biol Bioenergy. 2016;8:48194. https://doi.org/10.1111/gcbb.12289.

24. Joniec J, Frąc M. Microbial functional diversity (CLPP) and enzymatic activity in the soil degraded by sulphur mining, subjected to reclamation with various waste. Int Agrophys. 2017;31:465-73. https://doi.org/10.1515/intag-2016-0078.

25. Kara EE, Arli M, Uygur V. Effects of the herbicide Topogard on soil respiration, nitrification and denitrification in potato-cultivated soils differing in pH. Biol Fertil Soils. 2004;39:474-8. https://doi.org/10.1007/s00374-004-0729-3.

26. Kumar S. Effect of endosulfan and chlorpyrifos on protease activity in the cultivated soil. Int J Advan Eng Technol. 2011;2:188-92.

27. Kuźniar A, Banach A, Stępniewska Z, Frąc M, Oszust K, Gryta A, Kłos M, Wolińska A. Community-level physiological profiles of microorganisms inhabiting soil contaminated with heavy metals. Int Agrophys. 2018;32:101-9. https://doi.org/10.1515/ intag-2016-0096.

28. la Cecilia D, Maggi F. Analysis of glyphosate degradation in a soil microcosm. Environ Pollut. 2018;233:201-7. https://doi.org/10. 1016/j.envpol.2017.10.017.

29. Ladd JN, Butler JHA. Short - term assays of soil proteolytic enzyme activities using proteins and dipeptide derivatives as substrates. Soil Biol Biochem. 1972;4:9-30. https://doi.org/10. 1016/0038-0717(72)90038-7.

30. Lutman PJW, Swee J, Bery K, Law J, Payne R, Simpson E, Walker $\mathrm{K}$, Wightman P. Weed control in conventional and herbicide tolerant winter rapeseed (Brassica napus) grown in rotations with winter cereals in the UK. Eur Weed Res Soc. 2008;48:408-19. https://doi.org/10.1111/j.1365-3180.2008.00643.x.

31. Lv T, Zhang Y, Carvalho PN, Zhang L, Button M, Arias C, Weber KP, Brix H. Microbial community metabolic function in 
constructed wetland mesocosms treating the pesticides imazalil and tebuconazole. Ecol Eng. 2017;98:378-87. https://doi.org/10. 1016/j.ecoleng.2016.07.004.

32. Martin JP. Use of acid rose bengal and streptomycin in the plate method for estimating soil fungi. Soil Sci. 1950;69:215-32. https://doi.org/10.1097/00010694-195003000-00006.

33. Mommer L, Kirkegaard J, Ruijven J. Root - root interactions: towards a rhizosphere framework. Trends Plant Sci. 2016;21:209_ 17. https://doi.org/10.1016/j.tplants.2016.01.009.

34. Muñoz-Leoz B, Garbisu C, Antigüedad I, Ruiz-Romera E. Fertilization can modify the non-target effects of pesticides on soil microbial communities. Soil Biol Bioch. 2012;48:125-34. https:// doi.org/10.1016/j.soilbio.2012.01.021

35. Nguyen DB, Rose MT, Rose TJ, Morris G, van Zwieten L. Impact of glyphosate on soil microbial biomass and respiration: a metaanalysis. Soil Biol Biochem. 2016;92:50-7. https://doi.org/10. 1016/j.soilbio.2015.09.014.

36. Nivelle E, Verzeaux J, Chabot A, Roger D, Spicher F, Lacoux J, Nava-Saucedo JE, Catterou M, Tétu T. Does nitrogen fertilization history affects short-term microbial responses and chemical properties of soils submitted to different glyphosate concentrations? PLoS ONE. 2017;12(5):e0178342. https://doi.org/10.1371/journ al.pone. 0178342 .

37 Nowosielski O. Methods for determination of fertilization demand. Warsaw: PWRiL; 1981.

38. Oleszczuk P, Jośko I, Kuśmierz M, Futa B, Wielgosz E, Ligęza S, Pranagal J. Microbiological, biochemical and ecotoxicological evaluation of soils in the area of biochar production in relation to polycyclic aromatic hydrocarbon content. Geoderma. 2014;213:502-11. https://doi.org/10.1016/j.geoderma.2013.08. 027 .

39. Oszust K, Frąc M, Lipiec J. Soil microbial functionality in response to dairy sewage sludge and mineral fertilisers application under winter rape. Int J Environ Sci Technol. 2015;12:3675-84. https://doi.org/10.1007/s13762-015-0807-0.

40. Partoazar M, Hoodaji M, Tahmourespour A. The effect of glyphosate application on soil microbial activities in agricultural land. Afr J Biotechnol. 2011;10:19419-24. https://doi.org/10.5897/ AJB11.2440

41. Peruzzo PJ, Porta AA, Ronco AE. Levels of glyphosate in surface waters, sediments and soils associated with direct sowing soybean cultivation in north pampasic region of Argentina. Environ Pollut. 2008;156:61-6. https://doi.org/10.1016/j.envpol.2008.01.015.

42. Pohland B, Owen B. Biolog EcoPlates standard methods. Hayward: TAS Technical Bulletin Biolog; 2009;1:1-3.

43. Riah W, Laval K, Laroche-Ajzenberg E, Mougin Ch, Latour X, Trinsoutrot-Gattin I. Effects of pesticides on soil enzymes: a review. Environ Chem Lett. 2014;12:257-73. https://doi.org/10. 1007/s10311-014-0458-2.

44. Ramudu AC, Srinivasulu M, JafferMohiddin G, Rangaswamy V. Effect of fungicides on urease and protease activities in two groundnut (Arachis hypogaea L.) soils. Int J Environ Prot. 2012;2:23-8

45. Ranjith P, Udawatta A, Robert J, Kremer B, Stephen H, Anderson C, Harold E, Garrett D. Microbial resilience as influenced by an herbicide in soils from native prairie, CRP, and row crop management. 19th World Congress of Soil Science, Soil Solutions for a Changing World, Brisbane, Australia: 2010. ISBN 978-1-61839-102-5
46. Ratcliff AW, Busse MD, Shestak CJ. Changes in microbial community structure following herbicide (glyphosate) additions to forest soils. Appl Soil Ecol. 2006;34:114-24. https://doi.org/10. 1016/j.apsoil.2006.03.002.

47. Rühling A, Tyler G. Heavy metal pollutions and decomposition of Spruce Needle litter. Oikos. 1973;24:402-15. https://doi.org/ $10.2307 / 3543816$.

48. Sebiomo A, Ogundero VW, Bankole SA. Effect of four herbicides on microbial population, soil organic matter and dehydrogenase activity. Afr J Biotechnol. 2011;10:770-8. https://doi.org/10.5897/ AJB10.989.

49. Soman C, Li D, Wander M, Kent AD. Long-term fertilizer and crop-rotation treatments differentially affect soil bacterial community structure. Plant Soil. 2017;413:145-59. https://doi.org/10. 1007/s11104-016-3083-y.

50. Stanaszek-Tomal E. Environmental factors causing the development of microorganisms on the surfaces of national cultural monuments made of mineral building materials-review. Coatings. 2020;10:1203. https://doi.org/10.3390/coatings 10121203.

51 Tabatabai MA, Bremner JM. Use of p-nitrophenyl phosphate for assay of soil phosphatase activity. Soil Biol Biochem. 1968;1:301-7. https://doi.org/10.1016/0038-0717(69)90012-1.

52. Tao L, Yang H. Fluroxypyr biodegradation in soils by multiple factors. Environ Monit Asses. 2011;175:227-38. https://doi.org/ 10.1007/s10661-010-1508-2.

53. Tautges NE, Sullivan TS, Reardon CL, Burke IC. Soil microbial diversity and activity linked to crop yield and quality in a dryland organic wheat production system. Appl Soil Ecol. 2016;108:25868. https://doi.org/10.1016/j.apsoil.2016.09.003.

54. Thalmann A. Zur Methodik der Bestimmung der dehydrogenaseactivität im boden mittels triphenyltetrazoliumchlorid (TTC). Landwirtsh Forsch. 1968;21:249-58.

55. Thomas AD, Elliot DR, Dougill AJ, Stringer LC, Hoon SR, Sen $\mathrm{R}$. The influence of trees, shrubs, and grasses on microclimate, soil carbon, nitrogen, and $\mathrm{CO}_{2}$ efflux: Potential implications of shrub encroachment for Kalahari rangelands. Land Degrad Dev. 2018;29:1306-16. https://doi.org/10.1002/ldr.2918.

56. Trolldenier G, Schholter M, Bode W, Hartmann A. Bacterial biomass. In: Schinner F, Öhlinger R, Kandeler E, Margesin R, editors. Methods in soil biology. Berlin: Springer; 1995. p. 12-46.

57 Upadhyay LSB, Dutt A. Microbial detoxification of residual organophosphate pesticides in agricultural practices. In: Patra JK, Vishnuprasad ChN, Das G, editors. Microbial biotechnology. Applications in agriculture and environment. Singapore: Springer; 2017. p. 225-42.

58. Zabaloy MC, Garland JL, Gomez MA. A integrated approach to evaluate impacts of the herbicides glyphosate, 2-4-D and metsulfurom- methyt on soil microbial communities in the pampas region. Argentina Appl Soil Ecol. 2008;40:1-12. https://doi.org/ 10.1016/j.apsoil.2008.02.004.

59 Zantua MI, Bremner JM. Comparison of methods of assaying urease activity in soils. Soil Biol Biochem. 1975;7:291-5. https:// doi.org/10.1016/0038-0717(75)90069-3.

Publisher's note Springer Nature remains neutral with regard to jurisdictional claims in published maps and institutional affiliations. 